УДК 342.924

DOI https: / / doi.org/10.32837 / yuv.v0i6.2065

\author{
B. Мороз, \\ здобувач \\ Національного авіаційного університету, \\ керуючий партнер \\ Адвокатського об’єднання «Супрема Лекс»
}

\title{
ПРОЦЕСУАЛЬНІ ОСОБЛИВОСТІ РОЗГЛЯДУ ПОДАТКОВИХ СПОРІВ ІЗ ЗАСТОСУВАННЯМ ПРИНЦИПУ НАЛЕЖНОЇ ОБАЧНОСТІ
}

Актуальність теми зумовлена об'єктивними процесами трансформації податкового законодавства як основи функціонування податкової системи крізь призму судових спорів.

Ключове місце в системі податкового права займає податкове адміністрування, яке загалом являє собою процедуру реалізації прав і обов'язків суб'єктів податкового права щодо узгодження й погашення податкових зобов'язань.

3-поміж основних проблем податкового адміністрування в Україні варто виділити: 1) недосконалість податкового законодавства в процесі здійснення основних форм податкового контролю; 2) дисбаланс інтересів податкових органів і платників податків.

3 урахуванням зазначених проблем системи податкового адміністрування в Україні актуальності набуває дослідження місця принципу належної обачності.

Суть принципу (доктрини) належної обачності полягає в тому, що платник податку - покупець не несе відповідальність у вигляді позбавлення права податковий кредит або витрати за податкові зловживання свого постачальника або його контрагентів, якщо він проявив належну обачність і обережність і йому не було відомо про зловживання своїх контрагентів.

Так, 16 січня 2020 року було прийнято законопроєкт № 1210 «Про внесення змін до Податкового кодексу
України щодо удосконалення адміністрування податків, усунення технічних і логічних неузгодженостей в податковому законодавстві», підписаний Президентом України 21 травня 2020 року (Закон № 466-IX), який, зокрема, переніс в законодавчу площину судову доктрину сумлінності платника податків (належної обачності). Згідно із зазначеним Законом особа вважається винною в скоєнні правопорушення, якщо в установленому законом порядку буде встановлено, що така особа мала змогу дотримуватись правил i норм, за порушення яких Кодексом передбачена відповідальність, але не вжито достатніх заходів для їх дотримання. Заходи вважаються достатніми, якщо контролюючий орган не доведе, що платник діяв нерозумно, недобросовісно і без належної обачності.

У межах цієї статті проаналізуємо процесуальні особливості реалізації судової доктрини належної обачності в процесі розгляду податкових спорів у вітчизняній судовій практиці.

Побудова та функціонування ефективної системи податкового адміністрування та розвитку податкового законодавства, в тому числі й аналіз реалізації судової доктрини належної обачності $€$ предметом наукових досліджень широкого кола вітчизняних та зарубіжних учених. Так, питання ефективності управління податками та гармонізації податкового законодавства 
знаходить своє відображення у працях Р. Блажко, Є. Усенко, Л. Воронової, М. Кучерявенко, Р. Ханової, В. Андрущенко, І. Лук'яненко, П. Мельника, I. Желтобрюх, І. Войтенко, І. Львової, С. Овсяннікова, І. Решетникова, Д. Толкачева, М. Шифмана та інших. Однак, попри велику кількість публікацій, що стосуються цієї тематики, залишається чимало дискусійних питань, зумовлених, насамперед, юридичною практикою.

Метою цієї статті є дослідження перспектив розвитку податкового законодавства та пошук шляхів підвищення ефективності системи податкового адміністрування 3 урахуванням особливостей застосування принципу належної обачності, а також усунення прогалин, сформованих неоднозначною судовою практикою.

Нині у сфері податкових спорів $€$ кілька судових доктрин: доктрина «ділової мети», доктрина «добросовісності платника», доктрина «бенефіціарного власника», доктрина «належної обачності», доктрина «необгрунтованої податкової вигоди». Однак, як зазначає $Є$. Усенко, судові доктрини в податкових відносинах не $€$ відокремленим абстрактним явищем, а зумовлюються предметом доказування, процедурами доказування і т.д. [1]. Предмет доказування в процесі розв'язання податкових спорів неможливо будувати виключно за рахунок посилання на норми матеріального права. Суспільні відносини набагато складніші, ніж та їхня форма, яка відображається в матеріальних приписах. Саме тому в процесі доказування, визначенні предмета доказування об'єктивно необхідно враховувати наявну судову практику, забезпечити обгрунтоване доведення позиціі, в тому числі шляхом посилань та врахування судових рішень. Судові доктрини, впливаючи на предмет доказування в процесі вирішення спорів у сфері податкових відносин, зумовлюють врахування специфічних обставин, які не відображаються в нормах матеріального права. Водночас судова практика вимагає вирішення подібних спорів незалежно від того, чи знайшли ці обставини відображення в чинних правових нормах.

Включення в предмет доказування фактів, які не відображені в законодавчих нормах, можливе, але робиться це вже поза межами відповідного законодавчого акта, на підставі врахування положень судових доктрин. При цьому важливо мати на увазі, що таке правило поведінки формується вже не законодавчими органами, а здійснюється судовою владою самостійно. Фактично, можна вести мову про виявлення і застосування судом норм, що не закріплені в нормативно-правових актах (позитивне право), але входять до механізму правового регулювання відповідних відносин, в площині яких виник податковий спір. Логічність такого підходу зумовлюється, зокрема, динамічністю розвитку суспільних відносин у сфері оподаткування, неповнотою правового регулювання цих відносин, завданням суду в процесі вирішення податкового спору забезпечити дотримання балансу між публічним і приватним інтересом в оподаткуванні, тобто основного критерію ефективності правового регулювання відносин у цій сфері.

Згідно з позицією I. Решетнікової, процес доказування, об'єктивне визначення предмета доказування і на підставі цього вироблення судових доктрин у податкових спорах спираються на теорію доказів, за якою факти, що становлять предмет доказування, необхідно диференціювати: а) факти, які підлягають безпосередньому вирішенню; б) факти, які належать до вирішення; в) факти, які не належать до суті спору. Зрозуміло, що останній різновид фактів не може бути враховано в процесі формування судового рішення та судової доктрини. Щодо перших двох типів фактів треба мати на увазі необхідність використання різних режимів доказування 
та різного впливу їх на предмет доказування. Всебічно дослідженими мають бути факти, які підлягають безпосередньому вирішенню, бо саме вони найбільш чітко виражають сутність справи. Факти, які належать до вирішення, не можна не враховувати, але в більш стриманих режимах. Навряд чи лише на цьому типі фактів можна будувати остаточне судове рішення [2].

Базисом виникнення та формування судових доктрин із податкових спорів виступають правові позиції судів. Так, на одній із правових позицій сформувалася й судова доктрина належної обачності, яка застосовується до податкових відносин в Україні з 2008 року, коли Судова палата в адміністративних справах Верховного Суду України у справі № 08/28 за позовом Товариства з обмеженою відповідальністю «Метпромсервіс» до ДПІ у Шевченківському районі м. Запоріжжя про визнання недійсним податкового повідомлення-рішення ухвалила постанову від 12 лютого 2008 року, якою було скасовано прийняту на користь платника податків ухвалу Вищого адміністративного суду України і направлено справу на новий розгляд до суду першої інстанції.

Скасовуючи ухвалу Вищого адміністративного суду України, Верховний Суд України зробив цікаві висновки:

- «... факт порушення контрагентами-постачальниками продавия своїх податкових зобов'язань може бути підставою для висновку про необгрунтованість заявлених платником податку вимог про надання податкової вигоди - відшкодування ПДВ із державного бюджету, якщо податковий орган доведе, що платник податку діяв без належної обачності й обережності $і$ йому мало бути відомо про порушення, які допускали його контрагенти ...»;

- «Задовольняючи позов, суди виходили тільки з наявності у пози- вача податкових накладних продавиів. Вони не взяли до уваги того, шо позивач протягом тривалого часу набував через посередників сировину, зокрема металобрухт, в осіб, які систематично не сплачували податки, діяльність яких мала ознаки фіктивного підприємництва, за юридичною адресою не знаходилися, не звітували про свою діяльність або подавали податкові декларації про відсутність такої, зареєстровані власники та посадові особи яких не визнають своєї причетності до їхньӧ діяльності, а також, щзо позивач, продавці та їхні постачальники працювали в одному сегменті ринку, у якому існують налагоджені стабільні зв'язки й учасники якого обізнані стосовно один одного».

Крім того, питання відповідальності платника податків - покупця за податкові зловживання своїх контрагентів знаходить своє вирішення i в практиці Європейського суду з прав людини, яка є обов'язковою для застосування в Україні під час розгляду подібних судових спорів. Так, у справі «Булвес» АД проти Болгарії (п. 71 рішення, датованого 22 січня 2009 року) Європейський суд із прав людини висловив позицію, яка в принципі узгоджується 3 доктриною належної обачності й обережності: платник ПДВ не має нести відповідальність за зловживання, скоєні його постачальниками, якщо платник ПДВ не знав про такі зловживання і не міг про них знати.

Сучасна судова практика в Україні з питання необхідності застосування принципу належної обачності є різноманітною та подекуди суперечливою. Так, наприклад, у Постанові Верховного Суду від 25 вересня 2019 року у справі № 823/530/15 Верховний Суд наполягає, що платник податків при виборі контрагента та укладенні 3 ним договорів має керуватися належною обачністю. Саме від цього залежить подальше фактичне виконання 
таких договорів, отримання прибутку та права на отримання певних преференцій, зокрема формування податкового кредиту з податку на додану вартість. У зазначеному судовому рішенні суд касаційної інстанції погодився з доводами платника податків, що чинне податкове законодавство не ставить у залежність право платника податків на податковий кредит від виконання податкового обов'язку іншими платниками - постачальниками товарів (послуг). Однак у разі встановлення в судовому процесі обставин, які свідчать, що платник податків був чи міг бути обізнаний щодо протиправної діяльності його контрагента, яка полягає в незаконній мінімізації податкових зобов'язань, зокрема у створенні штучних підстав для збільшення валових витрат та / чи податкового кредиту, або якщо платник податків діяв без належної обачності чи обережності під час вибору контрагента, який не виконує податкового обов'язку, за встановлених обставин, які спростовують реальність господарських операцій, отримана таким платником податків податкова вигода у вигляді права на податковий кредит є безпідставною.

3 іншого боку, є численна судова практика, яка стоїть на захисті платників податків, виходячи з обов'язку органу податкового контролю довести умисел платника податків на ухилення від сплати податків та обізнаність із недобросовісністю контрагента. Так, у Постанові Верховного Суду від 31 липня 2018 року у справі № 808/1507/16 Верховний Суд зазначив, що правові наслідки у вигляді виникнення права платника податку на формування витрат та податкового кредиту наступають лише в разі реального (фактичного) вчинення господарських операцій із придбання товарів (робіт, послуг) із метою їх використання у своїй господарській діяльності, що пов'язані з рухом активів, зміною зобов'язань чи власного капіталу платника та від- повідають економічному змісту, відображеному в укладених платником податку договорах, що має підтверджуватись належним чином оформленими первинними документами. Норми податкового законодавства не ставлять у залежність достовірність даних податкового обліку платника податків від дотримання податкової дисципліни його контрагентами, якщо цей платник (покупець) мав реальні витрати у зв'язку з придбанням товарів (робіт, послуг), призначених для використання у його господарській діяльності. Порушення певними постачальниками товару (робіт, послуг) у ланцюгу постачання вимог податкового законодавства чи правил ведення господарської діяльності не може бути підставою для висновку про порушення покупцем товару (робіт, послуг) вимог закону щодо формування витрат та податкового кредиту, тому платник податків (покупець товарів (робіт, послуг)) не має зазнавати негативних наслідків, зокрема у вигляді позбавлення права на формування витрат чи податкового кредиту, за можливу неправомірну діяльність його контрагента за умови, якщо судом не було встановлено фактів, які свідчать про обізнаність платника податків щодо такої поведінки контрагента та злагодженість дій між ними.

Крім того, у Постанові Верховного Суду у складі колегіі суддів Касаційного адміністративного суду від 26 червня 2018 року у справі № 808/2360/17 зазначено, що суд вважає неприйнятними доводи відповідача про те, що сам факт того, що деякі контрагенти позивача фігурують в досудових розслідуваннях, порушених за ознаками кримінального правопорушення, є доказом протиправного формування податкового кредиту, з огляду на необгрунтованість належності цього конкретного доказу для підтвердження заперечень в розумінні ч. 3 ст. 73 Кодексу адміністративного судочинства України. Таким чином, посилання контролюючого 
органу на кримінальні провадження, відкриті за ознаками кримінального правопорушення, передбаченого ч. 1 ст. 205-1 Кримінального кодексу України щодо контрагентів позивача, обгрунтовано відхилені судом апеляційної інстанції, оскільки вказані не містять встановлених обставин, які б свідчили про невиконання контрагентами своїх договірних зобов'язань саме по господарських відносинах із позивачем або обставин, які б свідчили про фіктивність (нереальність) господарських операцій між вказаними суб'єктами господарської діяльності.

Також Верховний суд у справі № 804/16596/15 від 3 листопада 2020 року висловив думку, що норми податкового законодавства не ставлять у залежність достовірність даних податкового обліку платника податків від дотримання податкової дисципліни його контрагентами, якщо цей платник (покупець) мав реальні витрати у зв'язку з придбанням товарів (робіт, послуг), призначених для використання у його господарській діяльності. Порушення певним постачальником товару (робіт, послуг) у ланцюгу постачання вимог податкового законодавства чи правил ведення господарської діяльності не може бути підставою для висновку про порушення покупцем товару (робіт, послуг) вимог законодавства щодо формування податкового кредиту, тому платник податків (покупець товарів (робіт, послуг)) не має зазнавати негативних наслідків, зокрема у вигляді позбавлення права на формування податкового кредиту, за можливу неправомірну діяльність його контрагентів за умови, якщо судом не встановлено фактів, які свідчать про обізнаність платника податків щодо такої поведінки контрагентів та злагодженість дій між ними.

У процесі вирішення податкових спорів із застосуванням судової доктрини належної обачності варто пам'ятати, що відповідно до ч. 2 ст. 77 Кодексу адміністративного судочинства України в адміністративних справах про протиправність рішень, дій чи бездіяльності суб'єкта владних повноважень обов'язок щодо доказування правомірності свого рішення, дії чи бездіяльності покладається на відповідача, якщо він заперечує проти адміністративного позову. Тобто саме податкові органи мають довести, що платник податків знав та не міг не знати про порушення його контрагентом податкового законодавства.

На жаль, як ми побачили з деяких проаналізованих судових рішень, це не завжди так і суди забувають про положення ч. 2 ст. 77 КАС України, але, сподіваємось, що з урахуванням останньої судової практики та положень Закону № 466-IX платник податків зможе відчути себе більш захищеним.

Основною проблемою нині $€$ «розмитість» критеріїв належної обачності й обережності та ризики, що витікають із цього для платників податків, зокрема ризик надмірного податкового обтяження платника податків, якому будуть донараховані податкові зобов'язання.

Вбачаємо за необхідне надалі вдосконалити податкове законодавство України шляхом закріплення в ньому чітких критеріїв та правил для застосування принципу належної обачності, критеріїв оцінки ступеню участі кожного $з$ контрагентів у правопорушенні та відповідальності кожної відокремленої особи за порушення податкового законодавства, індивідуалізації такої відповідальності відповідно до вимог ст. 61 Конституції України.

Стаття присвячена питанням розвитку податкового законодавства крізь призму процесуальних особливостей розгляду податкових спорів із застосуванням принципу належної обачності. У межах статmi досліджено поняття податкового адміністрування, проблематику податкового адміністрування в 
Україні, визначено сутність принuуипу належної обачності, проаналізовано проблеми застосування принцииу належної обачності у вітчизняній судовій практиці та перспективи розвитку вітчизняного законодавства з метою уникнення ризиків застосування принциипу належної обачності. У межах статті встановлено, що cуть принципу (доктрини) належної обачності полягає у тому, що платник податку - покупець не несе відповідальність у вигляді позбавлення права на податковии кредит або витрати за податкові зловживання свого постачальника або його контрагентів, якщо він проявив належну обачність $i$ обережність $і$ йому не було відомо про зловживання своїх контрагентів. При цьому проаналізовано законодавчу новелу, якою закріплено, що особа вважається винною в скоєнні правопорушення, якщо в установленому законом порядку буде встановлено, шо така особа мала змогу дотриматись правил i норм, за порушення яких Кодексом передбачена відповідальність, але не вжила достатніх заходів для їх дотримання. Також досліджено критерії відповідальності платника податків за порушення принципу належної обачності, згідно з якими умисними, якщо є підтверджені контролюючим органом обставини, які свідчать, що платник удавано, иілеспрямовано створив умови, які не можуть мати іншої мети, крім невиконання або неналежне виконання вимог, встановлених Податковим Кодексом та іншим законодавством, контроль за яким покладено на контролюючі органи. Також обтрунтовано, щзо обов'язок доказування обізнаності платника податків із тим, що його контрагент порушив податкове законодавство, покладається на податкові органи як відповідача у відповідному податковому спорі.
Ключові слова: принцип належної обачності, податкове адміністрування, судові доктрини, податкові спори, судова практика, доктринальне положення.

Moroz V. Procedural features of consideration of tax disputes with application of the principle of due diligence

The article is devoted to the development of tax legislation through the prism of procedural features of tax disputes with the application of the principle of due diligence. The article examines the concept of tax administration, issues of tax administration in Ukraine, defines the essence of the principle of due diligence, the problems of application of the principle of due diligence in domestic judicial practice and prospects of development of the domestic legislation for the purpose of avoidance of existing risks of application of the principle of due diligence are analyzed. The article states that the essence of the principle (doctrine) of due diligence is that the taxpayer - the buyer is not liable in the form of deprivation of the right to a tax credit or the cost of tax abuse of its supplier or its counterparties only if he has shown due caution and he was not aware of the abuse of his counterparties. At the same time, a legislative novella was analyzed, which stipulates that a person is considered guilty of an offense if it is established in the manner prescribed by law that such a person had the opportunity to comply with the rules for which the Code provides liability, but did not take sufficient measures compliance. The criteria of the taxpayer's liability for breach of the principle of due diligence were also researched, according to which intentional, if there are circumstances confirmed by controlling body, which indicate that the taxpayer pretended to have purposefully 
created conditions that can have no purpose other than non-compliance or improper compliance establishes by the Tax Code and other legislation, the control of which is entrusted to the supervisory authorities. Moreover, it is justified that the obligation to prove the taxpayer's awareness that his counterparty has violated tax legislation rests with the tax authorities as the defendant in the relevant tax dispute.

Key words: the principle of due diligence, tax administration, legal doctrines, tax disputes, litigation, doctrinal position

\section{Література}

1. Усенко Є. Судові доктрини з податкових спорів як комплексна проблема узгодження чинного законодавства та судової практики. Науково-інформаційний вісник Івано-Франківського університету права імені Короля Данила Галицького: Серія Право. 2016. № 2(14). C. 98-102.

2. Решетникова И.В. Доказательственное право Англии и США / под ред. И.В. Решетниковой. 2-е изд.; перераб. и доп. Москва: Городеи, 1999. 402 с.

3. Блажко P. Доктрина належної обачності $i$ обережності. URL: https: / / taxua.blogspot.com / 2012 /03/ nalezhna-obachnist-i-oberezhnist.html (дата звернення 22.11.2020);

4. Львова I. Принщип презумпції правомірності рішень платника податків. Бухгалтерія. 2012. № 35. С. 27.

5. Толкачев Д.Д. Проблемы доказывания по делам из налоговых правоотношений в арбитражном проиессе : автореф. дис. ... канд. юрид. наук : 12.00.07. Москва, 2012. 27 c. 